\title{
Partial Purification and Characterization of Xylanase Produced by Penicillium expansum
}

\author{
André Luiz de Souza Querido ${ }^{1 *}$, Jorge Luiz Cavalcante Coelho ${ }^{1}$, Elza Fernandes de \\ Araújo $^{2}$ and Virgínia Maria Chaves-Alves ${ }^{1}$ \\ ${ }^{1}$ Laboratório de Fisiologia de Microrganismos; ${ }^{2}$ Laboratório de Genética de Microrganismos; BIOAGRO; \\ Departamento de Microbiologia; Centro de Ciências Biológicas e da Saúde; Universidade Federal de Viçosa; \\ andrequerido10@yahoo.com.br; 36570-000; Viçosa-MG - Brasil
}

\begin{abstract}
An extracellular xylanase was found to be the major protein in the filtrate culture of Penicillium expansum when grown on $0.3 \%$ wheat bran, which showed no xylanase multiplicity. The enzime was partial purified by.ammonium sulfate fractioning, molecular exclusion chromatography, ultrafiltration and anion exchange chromatography. The protein eluation profile showed only one form of xylanase that was partially characterized. The activity of purified xylanase was optimal at $\mathrm{pH} 5.5$ and $40{ }^{\circ} \mathrm{C}$. The enzyme was stable at $\mathrm{pH}$ between 5.5 and 6.5 and temperatures between $20-40{ }^{\circ} \mathrm{C}$. The enzyme showed a $\mathrm{Km}$ of $3.03 \mathrm{mM}$ and Vmax of $0.027 \mu \mathrm{mol} \mathrm{min}^{-1} \mu \mathrm{g}^{-1}$ of protein. The enzymatic activity was increased $31 \%$ by $\mathrm{Mg}^{2+}$ and $28 \%$ by $\mathrm{Al}^{3+}$.
\end{abstract}

Key words: Partial purification; xylan, xylanases; Penicillium expansum

\section{INTRODUCTION}

Microbial xylanases have important applications in the biodegradation of xylan, a biopolymer of lignocellulose biomass. In this process $\beta-1,4-$ xylanase (EC 3.2.1.8) plays a key role. Penicillium expansum is a filamentous fungus that produces extracellular Xylanase (Ferreira-Filho et al., 1993). Xylanase has applications in the last years, much in the paper and cellulose manufacturing, as in the textile and food industries. (Godfrey and West, 1996). Yimbo et al., (1996) purified and characterized a cellulase-free-xylanase from Aspergillus niger Chandra et al., (1996) isolated A. fisheri Fxn1 for xylanase production and purification. The aim of the present study was to partially purify and characterize xylanase produced by Penicillium expansum to identify possible genetic polymorphism and to determine the physical and chemical parameters of the enzyme, evaluating its applicability in textile industry.

\section{MATERIALS AND METHODS}

\section{Microorganism}

A strain of Penicillium expansum isolated from forest seeds was used in this study.

\section{Medium and Cultivation}

The cultivation of $P$. expansum was conducted in unbuffered mineral medium with the following composition (g/L): $\mathrm{K}_{2} \mathrm{HPO}_{4}, 0.62 ; \mathrm{KH}_{2} \mathrm{PO}_{4}, 2.0$; $\left(\mathrm{NH}_{4}\right)_{2} \mathrm{SO}_{4}, 1.0 ; \mathrm{MgSO}_{4} .7 \mathrm{H}_{2} \mathrm{O}, 1.1 ; \mathrm{pH} 6.3$; with yeast extract $0.06 \%(\mathrm{w} / \mathrm{v})$ and wheat bran $0.3 \%$

\footnotetext{
${ }^{*}$ Author for correspondence
} 
$(\mathrm{w} / \mathrm{v})$ as the sole carbon source. The culture was incubated in an orbital shaker at $150 \mathrm{rpm}, 25{ }^{\circ} \mathrm{C}$ for $120 \mathrm{~h}$. The resulting mycelial mass was separated from the culture medium by filtration.

\section{Enzyme Assay}

The enzymatic assay was done according to Haltrich et al., (1993). $\beta-1,4$-xylanase activity was determined by estimating the xylose liberated from oat spelt xylan $1 \% \quad(\mathrm{w} / \mathrm{v})$ suspended in phosphate buffer $50 \mathrm{mM}$, pH 5.0. The reduction sugar was determined by the DNS method (Miller, 1959) using xylose standard sugar. One unit of enzyme activity was defined as the amount $(\mu \mathrm{mol})$ of reducing sugar released per minute. Protein concentrations were determined by the method of Bradford (1976), with bovine serum albumin as a standard.

\section{Purification}

The culture filtrate was concentrated by lyophilization and resuspended in potassium phosphate buffer $0.05 \mathrm{M}, \mathrm{pH}$ 7.2. The crude enzyme was precipitated with ammonium sulfate at $60 \%$ saturation, and the precipitate was collected by centrifugation at $8000 \mathrm{~g}$ for $15 \mathrm{~min}$. Crude enzyme precipitate was dissolved in potassium phosphate buffer, $\mathrm{pH} 7.2,0.05 \mathrm{M}$, dialysed and applied $20 \mathrm{~mL}$ to exclusion column Sephadex G-25 (20x1000mm), pre-balanced in potassium phosphate buffer $0,05 \mathrm{M}, \mathrm{pH}$ 7.2. The fractions containing enzymatic activity were ultrafiltrated and applied $5 \mathrm{~mL}$ to anionicexchange column DEAE-Sephadex A-50 $(20 \times 150 \mathrm{~mm})$, pre-balanced in potassium phosphate buffer $0,05 \mathrm{M}, \mathrm{pH}$ 7.2. A linear gradient of $\mathrm{NaCl}(0-0,5 \mathrm{M})$ was applied. Eluted fractions of $3 \mathrm{~mL}$ were collected for the determination of the xylanase activity and absorbance at $280 \mathrm{~nm}$.

\section{Characterization}

Effect of temperature and $\mathrm{pH}$ on xylanase activity was measured at 20 and $70{ }^{\circ} \mathrm{C}$ and $\mathrm{pH} 4.0-9.0$, respectively. The $\mathrm{pH}$ was adjusted with $\mathrm{NaOH} 2$ $\mathrm{M}$ or $\mathrm{HCl} 2 \mathrm{M}$. The effect of ions $\mathrm{Mg}^{2+}$ and $\mathrm{Al}^{3+}$, applied as $\mathrm{MgSO}_{4}(1 \mathrm{mM})$, and $\mathrm{AlPO}_{4}(1 \mathrm{mM})$ on xylanase activity was studied by addition of the ions to the substrate xylan at optimal $\mathrm{pH}$ and temperature. Kinetic constants for xylanase were determined using concentrations varying between
1.0 and $60.0 \mathrm{mg} / \mathrm{mL}$ of xylan substrate in potassium phosphate buffer $0,05 \mathrm{M}$, at $\mathrm{pH} 5.5$ and optimal temperature. The Michaelis-Menten constant $\left(\mathrm{K}_{\mathrm{m}}\right)$ and maximal velocity $\left(\mathrm{V}_{\max }\right)$ were determined using the method of double reciprocals (Lineweaver and Burk, 1934). All xylanase activity values are provided as the means of three replication.

\section{RESULTS AND DISCUSSION}

The elution profile of proteins showed a single form of xylanase, which was partially characterized (Figs 1-2). An activity peak was eluted during the lineal gradient of $\mathrm{NaCl}(0,1 \mathrm{M})$.

The profile of elution in the DEAE-Sephadex A50 suggested that only one xylanase was produced. Electrosphoresis in SDS polyacrylamide gel (12 $\%$, stained with silver nitrate) showed that a good purification (Fig 3).

The activity of partially purified $\beta-1,4$-xylanase was optimal at pH 5.5 and $40{ }^{\circ} \mathrm{C}$. Similar results were observed for other microorganisms. $P$. chrysogenum (Haas et al., 1992) and A. ficheri Fxn1 (Chandra et al., 1996) also presented xylanases with maximum activities at similar $\mathrm{pH}$. Kitamoto et al. (1999) found a $\mathrm{pH}$ of 5.0 as optimum for a xylanase produced by A. oryzae. Sherief (1990) found an optimal $\mathrm{pH}$ of 5.0 for a xylanase of $A$. flavipes. The xylanases of fungal origin usually show optimal activity around $50{ }^{\circ} \mathrm{C}$, being inactivated at $65{ }^{\circ} \mathrm{C}$ (Gaspar et al., 1997). Kitamoto et al. (1999) observed an optimal temperature of $60{ }^{\circ} \mathrm{C}$ for the xylanase produced by A. oryzae, whereas Sherief (1990) found an optimal temperature of $55{ }^{0} \mathrm{C}$ for a xylanase produced by A.flavipes.

The xylanase was stable at temperatures between 20 and $40{ }^{\circ} \mathrm{C}$. The activity dropped to less than $48 \%$ between 50 and $70{ }^{\circ} \mathrm{C}$. The same happened to polygalacturonases (PG) produced by Trichoderma resei QM 9414, which was inactivated when maintained during one hour above $45{ }^{0} \mathrm{C}$ (Dekker, 1993). Thermal stability however, to higher temperatures could be increased after the addition of $1 \mathrm{mg} / \mathrm{mL}$ of of bovine serum albumin (BSA) prevening the enzymatic inactivation significantly. 


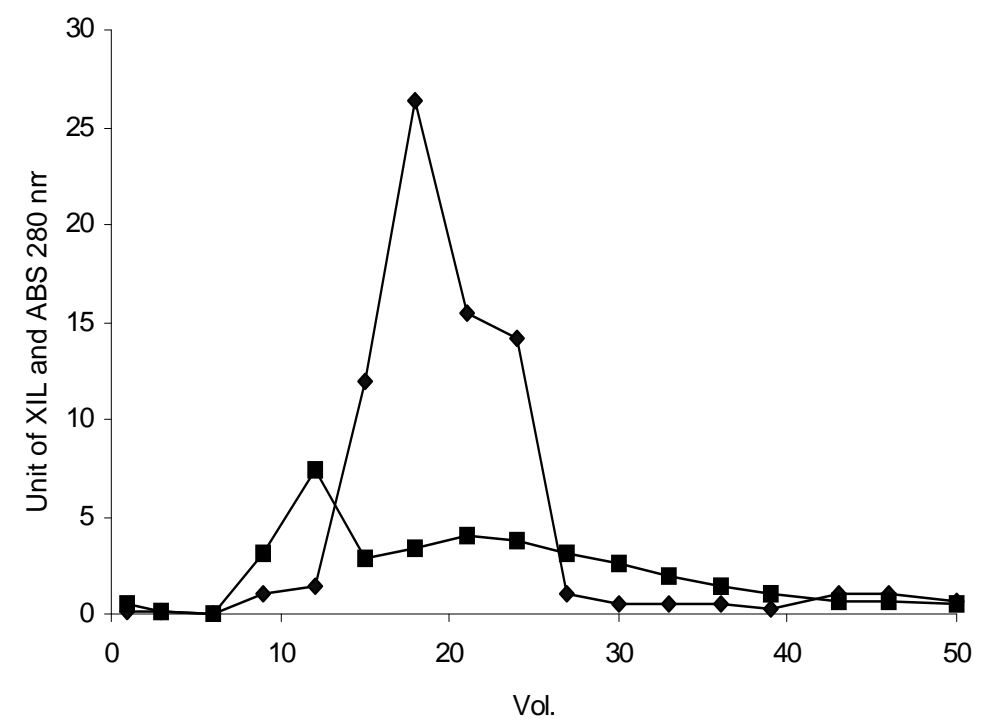

Figure 1 - Elution profile by molecular exclusion chromatography in the Sephadex G-25. $(\diamond)$ xylanase activity $(\mathrm{u}) ;(\boldsymbol{\square})$ absorbance at $280 \mathrm{~nm}$.

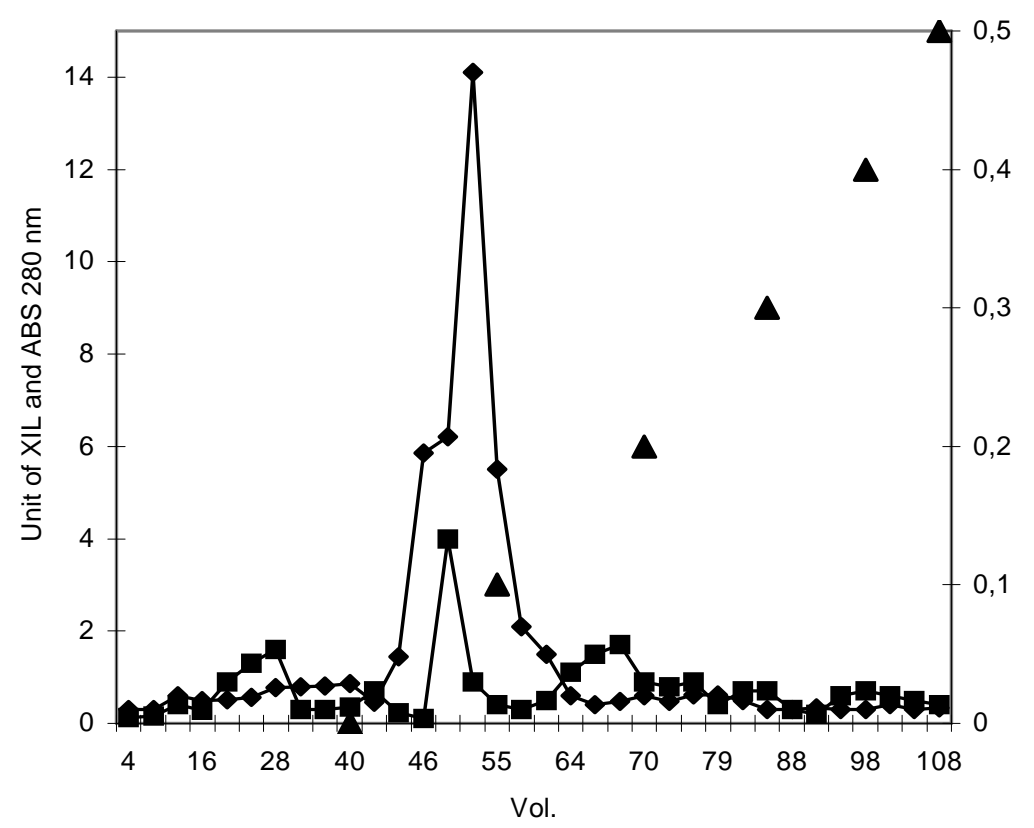

Figure 2 - Elution profile by anionic exchange chromatography in the DEAE-Sephadex A-50. ( ) xylanase activity (u); ( $)$ absorbance at $280 \mathrm{~nm} ;(\boldsymbol{\Delta}) \mathrm{NaCl}$ gradient 0-0,5 M. 
Table 1 - Resume of stages of the partial purification of xylanase of P. Expansum.

\begin{tabular}{cccccc}
\hline Stage & $\begin{array}{c}\text { Protein } \\
(\boldsymbol{\mu g})\end{array}$ & $\begin{array}{c}\text { Activ. } \\
(\mathbf{U})\end{array}$ & $\begin{array}{c}\text { Specific } \\
\text { activity }\end{array}$ & $\begin{array}{c}\text { Yield } \\
(\boldsymbol{\%})\end{array}$ & $\begin{array}{c}\text { Purif. } \\
\text { Factor }\end{array}$ \\
\hline Supernatant & 190000 & 50321 & 0.26 & 100 & 1 \\
$\left(\mathrm{NH}_{4}\right)_{2} \mathrm{SO}_{4}$ & 29000 & 20621 & 0.71 & 49.2 & 2.7 \\
Gel Filtration & 3600 & 3050 & 0.84 & 5.7 & 3.2 \\
Ultrafiltration & 2170 & 2600 & 1.19 & 4.8 & 4.5 \\
Ion Exchange & 374 & 725 & 1.93 & 1.3 & 7.4 \\
\hline
\end{tabular}

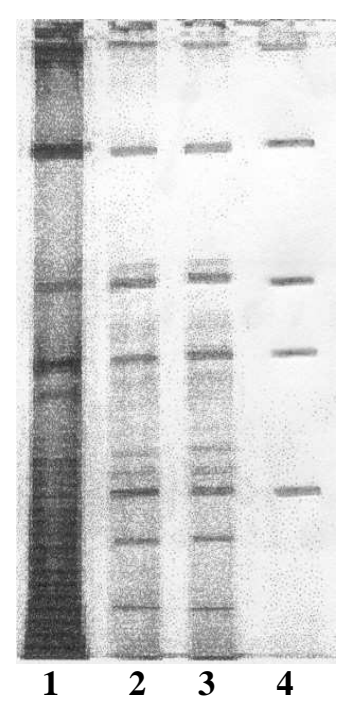

Figure 3 - Electrophoresis in SDS-polyacrylamide ge1 $12 \%$, stained with silver nitrate. 1. Supernatant of the culture; 2. After molecular exclusion colunm; 3. After ultrafiltration; 4. After ionic exchange column.

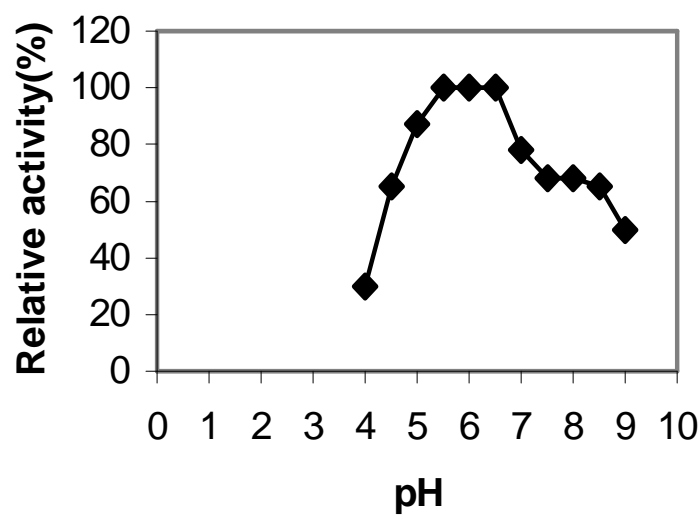

Figure 4 - Stability of xylanase to $\mathrm{pH}$. Relative activity was determined at $\mathrm{pH} 5.5,40^{\circ} \mathrm{C}$, after $1 \mathrm{~h}$.

The xylanase was stable at $\mathrm{pH}$ between 5.5-6.5. The enzyme retained about 78, 87 and $65 \%$ of its optimal activity at $\mathrm{pH} 7.0, \quad 5.0$ and 4.5 , respectively. The activity dropped to $68 \%$ of its optimal value at $\mathrm{pH}$ between 7.5 and 8.5 ; to $50 \%$ at $\mathrm{pH} 9.0$, and to $30 \%$ at $\mathrm{pH} 4.0$ (Fig 4). The 
xylanases of fungal origin are more active at $\mathrm{pH}$ that oscillates between 3.5 and 5.5 but are quite stable over a wide $\mathrm{pH}$ range (3.0 to 10.0). On the other hand, the optimal $\mathrm{pH}$ of the bacterial xylanases oscillates among $\mathrm{pH} 5.0$ and 7.5 (Dekker, 1993). The xylanase produced from alkali-tolerant Thermophiles was shown to be stable at $\mathrm{pH}$ 5.5-9.5 (strain SP) and $\mathrm{pH}$ 6.0-7.5 (strain BC) after 30 minutes of incubation at $60{ }^{\circ} \mathrm{C}$ (Plamen et al., 1997).

Approximately a third of the known enzymes possess metals as part of their structures (Conn and Stumpf, 1987). The effect of the $\mathrm{Mg}^{2+}$ and $\mathrm{Al}^{3+}$ was shown in Table $2 . \mathrm{Mg}^{2+}$ increased the activity of the enzyme by $31 \%$ and $\mathrm{Al}^{3+}$ increased the activity of the enzyme by $28 \%$.

For xylanases of A.ficheri Fxn1, $\mathrm{Mg}^{2+}(10 \mathrm{mM})$ didn't show any effect whereas $\mathrm{AlCl}_{3}(10 \mathrm{mM})$ decreased the activity by $95 \%$ (Chandra et al., 1996). Ghareib (1992) demonstrated that $\mathrm{Zn}^{2+}, \mathrm{Cu}$ ${ }^{2+}, \mathrm{K}^{+}$and $\mathrm{Co}^{2+}$ increased the xylanolitic activity of A. terreus, but $\mathrm{HgCl}_{2}, 2$,4-dinitrophenol (DNP) and diamino ethylene acetic acid (EDTA) strongly inhibited the activity at $1 \mathrm{mM}$.

Table 2 - Ions effect about the activity of the xylanase of $P$. expansum partially purified.

\begin{tabular}{cc}
\hline Composed added (1 $\mathbf{~ m M})$ & Relative activity (\%) \\
\hline Control (without addition) & 100 \\
$\mathrm{MgSO}_{4}$ & 131 \\
$\mathrm{AlPO}_{4}$ & 128 \\
\hline
\end{tabular}

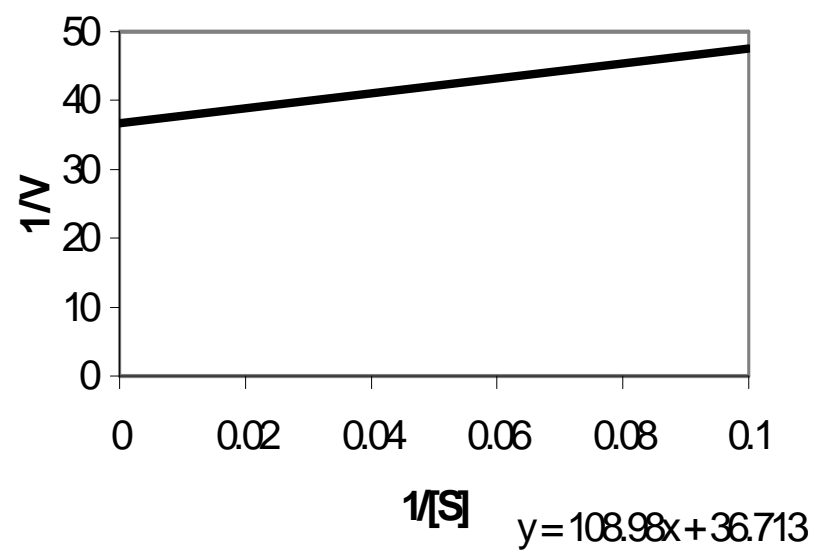

Figure 5 - Kinetics of the xylan hydrolysis for xylanase. Graphic representation of Lineweaver-Burk.

The $\left(\mathrm{K}_{\mathrm{m}}\right)$ and $\left(\mathrm{V}_{\max }\right)$ were calculated to be 3.03 $\mathrm{mM}$ and $0.027 \mu \mathrm{mol} \min ^{-1} \mu \mathrm{g}{ }^{-1}$ of protein, respectively (Fig 5). This was in the same range of value of $\mathrm{Km}$ and $\mathrm{V}_{\max }$ of the main xylanase of alkali tolerant A.fischeri Fxn1 (Chandra et al., 1996), which was $4.88 \mathrm{mM}$ and Vmax $0.058 \mu \mathrm{mol}$ $\min ^{-1} \mu \mathrm{g}^{-1}$ of protein. On the other side, the values of the $\mathrm{Km}$ of the xylanase of Acrophialophora nainiana were $40.9 \mathrm{mM}$ and $16.1 \mathrm{mM}$, respectively (Salles et al., 2000).

\section{CONCLUSION}

Based on the above results, it was concluded that P.expansum was a potentially interesting producer of a single form of a xylanolitic enzyme.

\section{ACKNOWLEDGMENTS}

This research was supported by CAPES. 


\section{RESUMO}

Uma xilanase extracelular foi encontrada como a principal proteína na cultura filtrada de Penicillium expansum quando cultivado em farelo de trigo 0,3 $\%$, a qual não mostrou multiplicidade. A enzima foi parcialmente purificada por fracionamento com sulfato de amônia, cromatografia de exclusão molecular, ultrafiltração e cromatografia de troca aniônica. O perfil de eluição das proteínas mostrou uma única forma de xilanase, sendo esta parcialmente caracterizada. A atividade da xilanase purificada foi ótima em $\mathrm{pH} 5.5$ e à temperatura de $40{ }^{\circ} \mathrm{C}$. A enzima foi estável em pH entre 5,5 e 6,5 e à temperatura entre $20-40{ }^{\circ} \mathrm{C}$. A enzima apresentou

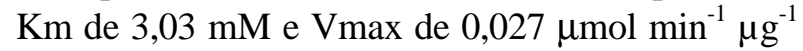
de proteína. A atividade enzimática foi aumentada $31 \%$ por $\mathrm{Mg}^{+2}$ e $28 \%$ por $\mathrm{Al}^{+3}$.

\section{REFERENCES}

Bradford, M. M. A. (1976), Rapid and sensitive method for quantitation of microgram quantities of protein utilizing the principlle of protein-dye binding. Analytical Biochemistry, 72, 248-254.

Chandra, T. S. and Chandra, K. (1996), Purification and characterization of xylanase from alkali-tolerant Aspergillus fischeri Fxn1. FEMS Microbiol. Lett. 145, 457-461.

Conn, E. E.; Stumpf, P. K. Bruening, G. and Doi, R. H. (1987), Outlines of Biochemistry. Ed.Jonh Wiley and Sons, Inc.

Dekker, R. F. H. (1993), Bioconversion of hemicellulose: aspects of hemicellulase production by Trichoderma reesei QM 9414 and enzymic saccharification of hemicellulose. Biotechnology and Bioengineering, 25, 1127-1146.

Ferreira-Filho, E. X.; Puls, J. and Coughalan, M. P.(1993), Biochemical characteristics of two endo1,4- $\beta$-D-xylanases isolated from solid state cultures of Penicillium capsulatum. Journal of Industrial Microbiology, 11, 171-180.

Gaspar, A.; Cosson, T.; Roque, C. and Thonart. (1997), Study on the production of a xylanolytic complex from Penicillium canescens 10-10c. Applied Biochemistry and Biotechnology, 67, 45-67.

Ghareib M. (1992), Purification and general properties of xylanase from Aspergilus terreus. Zentralbl Mikrobiology Nov; 147 : (8), 569-76.

Godfrey, T. and West, S. I. (1996), Introdution to industrial enzymology. In: Godfrey, T. and West, S. (Eds.). Industrial Enzimology. $2^{\text {nd }}$ ed. MacMillam Press LTD. 609 pp.
Haltrich, D.; Preiss, M. and Steiner, W. (1993), Optimization of a culture medium for increased xylanase production by a wild strain of Schizophyllum commune. Enzyme microbiology technology, 15, 854-860.

Haas, H.; Herfurth, E.; Stoffler, G. and Redl, B. (1992), Purification, characterization and partial aminoacid sequences of xylanase produced by Penicillium chrysogenum. Biochmica et Biophysica Acta, 1117 : (3), 279-286.

Kimura, I. and Tajima, S. (1998), The modes of action of two endo-1,4- $\beta$-D-xylanases from Aspergillus sojae on various xilogosaccharides. Journal of Fermentation and Bioengineering, 85 : (3), 283-288.

Kitamoto N.; Yoshino S.; Ohmiya K. and Tsukagoshi N. (1999), Purification and characterization of overexpressed Aspergillus oryzae xylanase, XynF1. Bioscience Biotechnology Biochemistry, 63 : (10), 1791-1794.

Khasin, A.; Alchanati, I. and Shoham,Y. (1993), Purification and characterization of thermostable xylanase from Bacillus stearothermophilus T-6. Applied and Environmental Microbiology, v.59, p.1725-1730.

Lineweaver, H. and Burk, D. (1934), The determination of enzyme dissociation constants. Journal American Chemical Society, 56, 658-666.

Miller, G. L. (1959), Use of dinitrosalicylic acid for determination of reducing sugar. Analytical Chemistry, 31, 424-426.

Plamen, L. D.; Margarita, S, K; Rossica, D. M. and Elka, I. E. (1997), Isolation and characterization of xylan-degrading alkali-tolerant thermophiles FEMS Microbiology Letters., 157, 27-30.

Salles, B. C; Cunha, R. B; Fontes, W.; Souza, M. V. and Filho, E. X. (2000), Purification and characterization of a new xylanase from Acrophialophora nainiana. Journal Biotechnology, 81 : (2-3), 199-204.

Sherief, A. A. (1990), Separation and some properties of an endo-1,4-beta-D-xylanase from Aspergillus flavipes. Acta Microbiology Hung, 37 : (3),301-306.

Wong, K .K. Y.; Tam, L. U. L. and Saddler, J. N. (1988), Multiplicity of 1,4 xylanase in microrganisms: functions and aplications. Microbiological Reviews, 52, 305-317.

Yimbo,Q.; Peiji, G.; Dong, W.; Xin, Z. and Xiao, Z. (1996), Production, characterization and application of the cellulase-free-xylanase from Aspergillus niger. Applied Biochemistry and Biotechnology, 57/58, 375-381.
Received: April 16, 2004; Revised: January 10, 2005; Accepted: January 09, 2006. 